\title{
Młodopolski romans popularny \\ - kłopoty z teorią
}

ABSTRACT. Pochłódka Anna, Młodopolski romans popularny - kłopoty z teoria The popular romance of Young Poland - trouble with the theory]. "Przestrzenie Teorii" 9. Poznań 2008, Adam Mickiewicz University Press, pp. 121-141. ISBN 978-83-232-1917-0. ISSN 1644-6763.

This article offers an outline of the history of theoretical interest in popular literature, in particular - romance. The author discusses mainly the research propositions developed on Polish grounds, starting with the differentiation of elite or 'highly artistic' literature and the popular one. Following Jacek Kolbuszewski, the author proposes to determine the range of popular literature on cultural instead of sociological basis. Also Anna Martuszewska's notion is supported, who claims that popularity is an immanent feature of this kind of literature. The question of probability in the Young Poland romance is considered as well. The methodological ideas are illustrated by references to specific novels.

Popular fiction is multiform and set in the artistic, historical and sociological context. Relating to the presented material, the author proposes a thesis that in the period of Young Poland two currents of romantic fiction coexisted: the 'tendentious-fabulous' (represented by Anna Karwatowa nee Bardzka, Natalia Bardzka, Wanda Grot-Bęczkowska, Helena Mniszkówna) and the 'naturalistic' one (represented by Mikołaj Czerny, Marian Gawalewicz, Mieczysław Srokowski, Kazimierz Przerwa Tetmajer). It is determined upon the inherent characteristics of particular texts (i.e. style, construction of hero, manner of creation of the presented world, etc.) which current a novel represents.

Młoda Polska uznawana bywa za okres inicjalny dla wielu ważnych w XX w. zjawisk i procesów kulturowych. Zaliczają się do nich powstanie i rozwój literatury popularnej. To brzmiące jak obojętna konstatacja sformułowanie kryje skomplikowaną i bogatą problematykę, wciąż niecałkowicie przebadaną, a $\mathrm{w}$ dodatku kłopotliwą. Trudno bowiem wyszczególnić właściwości literatury popularnej, nazwać jej relacje z literaturą elitarną, wyodrębnić jej odbiorców i scharakteryzować autorów. Nie ma zgody nawet co do tego, czy do badania literatury popularnej w ogóle nadają się kategorie opracowane na gruncie historii literatury parającej się twórczością wysokoartystyczną.

$\mathrm{W}$ tej sytuacji zacząć należy od tego, co wiadome. Jednym $\mathrm{z}$ gatunków, jednomyślnie zaliczanych do literatury popularnej jest romans, którego bujny rozwój nastąpił w okresie Młodej Polski ${ }^{1}$. Nowoczesny romans

1 Polemizuję z tezą M. Bujnickiej, przedstawioną w pracy Erotyka romansu popularnego. Konteksty $i$ podteksty, „Literatura Ludowa” 1985: 1-2, oraz w artykule Romans popularny - baśń kultury masowej, w: Modele świata i czlowieka. Szkice o powieści wspól- 
to powieść, której fabuła skoncentrowana jest wokół uczucia miłości, łączącego protagonistów, zaś akcja zawiera napędzane tym uczuciem perypetie. Inne wątki są albo marginalne, albo podporządkowane miłości, albo w ogóle nieobecne. Konstrukcja fabuły oparta jest na powtórzeniu, gradacji i kontraście ${ }^{2}$, zarówno w zakresie przedstawionych wydarzeń, jak i natężenia emocji. Przejrzystość kompozycji, paralelne lub krzyżujące się linie napięć i „nieprzejrzystość” (sztuczność, wyszukana ozdobność) języka, głównie w scenach miłosnych - to najważniejsze cechy romansu ${ }^{3}$.

Początek polskiej refleksji na temat literatury popularnej przypada na przełom lat sześćdziesiątych i siedemdziesiątych XX w. Pojawiło się wówczas zaskakująco dużo szkiców czy prób, jak i ważnych, dojrzałych koncepcji badawczych. Rekonstrukcję polskiego stanu badań literatury popularnej rozpoczyna się zwykle od Czesława Hernasa, który wskazuje na potrzebę badania literatury brukowej - „trzeciej”, obok literatury wysokoartystycznej i folkloru4. Zalicza do niej powieści zeszytowe, piosenkę popularną, balladę uliczną, pieśń dziadowską, kalendarze, powiastki i tym podobne. Rozprowadzane one były z początkiem XX wieku wśród świeżo władających umiejętnością czytania odbiorców - chłopów, którzy zostali wyrwani $\mathrm{z}$ zakorzenienia $\mathrm{w}$ folklorze przez gwałtowne zmiany społeczne, związane $\mathrm{z}$ narastającą industrializacją. Ta literatura „rynkowa” czy „brukowa” miała zastąpić zapomniane, tradycyjne formy, wprowadzając jednocześnie własne tradycje.

Dobitnym wyrazem zainteresowania tą problematyką jest tom Formy literatury popularnej pod redakcją Aleksandry Okopień-Sławińskiej5. Należy też wspomnieć teksty Teresy Walas, wyrażające zaciekawienie

czesnej, red. J. Święch, Lublin 1985. Badaczka twierdzi tam, że romans popularny jako gatunek objawil się w momencie wydania Trędowatej - od razu w formie doskonałej; trwal zaś do 1939 r., czyli do wybuchu II wojny światowej, która miała tak radykalnie zmienić sytuację komunikacyjną, że pisanie takich romansów stało się niemożliwe. Przeczy temu empiria, i to w sposób zgoła dotkliwy - istnieją powojenne kontynuacje Trędowatej, pióra bezimiennych autorów, opisujące losy dziedziców ordynata w PRL-u. Książki te są świadectwem postępującej degradacji wzorca, jakim okazała się Trędowata, ale zarazem potwierdzają jego trwałą atrakcyjność.

2 M. Bujnicka, Romans popularny - baśń kultury masowej, op. cit, s. 62.

${ }^{3}$ M. Bujnicka, Romans (hasło), w: Slownik literatury popularnej, red. T. Zabski, Wrocław 1997. Trzeba zwrócić uwagę, ze w cytowanej definicji autorka wymienia cechy właściwe przede wszystkim romansom z początku wieku. Są to więc właściwości romansu młodopolskiego czy międzywojennego, ale nie każdego. Por. rozważania Joanny Pyszny na temat powieści hollywoodzkich: J. Pyszny, Miłość $w$ czasach popkultury, w: A. Martuszewska, J. Pyszny, Romanse z różnych sfer, Gdańsk 2003.

${ }^{4}$ C. Hernas, Potrzeby $i$ metody badania literatury brukowej, w: O wspólczesnej kulturze literackiej, red. S. Źbłkiewski, M. Hopfinger, t. 1, Wrocław 1973.

${ }^{5}$ Formy literatury popularnej, red. A. Okopień-Sławińska, Wrocław 1973. 
literaturą popularną okresu międzywojennego ${ }^{6}$, oraz studia Józefa Nowakowskiego ${ }^{7}$.

Wydaje się, że rozbudzenie zainteresowania literaturą popularną wiązało się z wypłynięciem interesujących perspektyw badawczych socjologii literatury. Tom Problemy socjologii literatury pod redakcją Janusza Sławińskiego ${ }^{8}$ zawiera kilka ważnych, inspirujących propozycji metodologicznych (jak na przykład projekt socjologii form literackich Sławińskiego ${ }^{9}$. Po trzydziestu latach widać jednak, że możliwości te nie zostały w pełni wykorzystane ${ }^{10}$.

Początkowy impet badań osłabł, choć problem badawczy nie został rozwikłany. Do najważniejszych współczesnych polskich badaczy należą Anna Martuszewska, Jacek Kolbuszewski i Piotr Kowalski. Trzeba przywołać również propozycje metodologiczne Marii Bujnickiej. W artykule Romans popularny - „Trędowata”. Propozycja lektury11 badaczka kreśli program analizy funkcjonalnej czy semiotycznej (różnica nie jest tu uderzająca) i rzeczywiście analizę, bardzo zresztą ciekawą, przeprowadza, ale propozycja metodologiczna pozostaje rozmyta.

Z kolei Agnieszka Fulińska próbuje zebrać i scalić sposoby badania literatury popularnej12. Konstatacja metodologicznego rozwodu między narzędziami egzo- i ergotekstowymi skłania ją do postulowania terapii małżeńskiej w postaci metody syntetycznej, łączącej dwa typy ujęć. To podejście pozwala zwrócić uwagę na niejednorodność materiału, określanego zbiorczo, niewygodnie i inercyjnie mianem kultury popularnej.

Warto zatrzymać się nad kwestią nazwy. Padały różne propozycje wyodrębnienia przedmiotu badań, poczynając od Hernasowych literatur „brukowej” czy „rynkowej”, przez inspirowane badaniami niemieckimi pojęcia „literatury trywialnej”, „literatury rozrywkowej” i Schemaliteratur ${ }^{13}$,

${ }_{6}^{6}$ T. Walas, Bez szlachectwa. (O międzywojennej powieści popularnej), „Życie Literackie" 1969:30.

7 J. Nowakowski, Proza Z. Bartkiewicza, J. Germana, A.A. Konara. Tradycja-dekadencja-przygoda, Rzeszów 1976; W kręgu obiegowych ideatów estetycznych, Rzeszów 1980.

8 Problemy socjologii literatury, red. J. Sławiński, Wrocław 1971.

9 J. Sła w iń ski, Socjologia literatury i poetyka historyczna, w: Problemy socjologii literatury, op. cit., s. 29-58.

$10 \mathrm{~W}$ znanych mi tekstach do pomysłu Sławińskiego odnosi się tylko Anna Martuszewska, zob. np. A. Martuszewska, Jak szumi „Dewajtis”? Studia o powieściach Marii Rodziewiczówny, Kraków 1989, s. 73-74.

${ }_{11}$ M. Bujnicka, Romans popularny - „Trędowata”. Propozycja lektury, „Literatura Ludowa" 1988:2.

12 A. Fulińska, Dlaczego literatura popularna jest popularna? „Teksty Drugie” 2003:4(82).

13 Por. A. Martuszewska, „Ta trzecia”. Problemy literatury popularnej, Gdańsk 1999, s. 29-39. 
propozycję Edwarda Balcerzana - literatura koniunkturalna ${ }^{14}$, mowa była o „sztuce łatwej”"15, pośrednio o kiczu ${ }^{16}$, o literaturze masowej. Choć często bywają traktowane jako synonimy, nie wszystkie te pojęcia dotyczą tego samego. Jak wskazuje Zbigniew Jarosiński zarówno literatura wysokoartystyczna, jak i popularna,

znajdują się naprzeciw literatury brukowej, która w całości rozgrywa się w sferze jednostkowej i zbiorowej nieświadomości, między przerażeniem a pożądaniem ${ }^{17}$.

O ile można mieć wątpliwości co do całkowicie „nieświadomościowej” konstrukcji czy recepcji jakiegokolwiek tekstu, o tyle Jarosiński słusznie odróżnia literaturę popularną od brukowej18.

Najmocniej ugruntowany jest chyba jednak termin „literatura popularna" i nawet niechętnie wobec niego nastawieni badacze złożyli broń. Wydaje się więc, że propozycja nowego terminu na określenie zjawiska mija się z celem, ponieważ nazwa „literatura popularna” ma już poważną tradycję badawczą i, jak zaznacza Anna Martuszewska, nie jest zbytnio obciążona pejoratywnym nacechowaniem.

W 1973 roku ukazał się ważny tekst Stefana Żółkiewskiego, próbujący wyznaczyć wyjściowe ramy dwudziestowiecznej polskiej kultury masowej19. Podobnie jak w innych swoich tekstach Żółkiewski zwraca uwage na zaistnienie $w$ okresie międzywojnia nowego odbiorcy $\mathrm{i}$ obiegu. Jego zdaniem, rok 1918 inicjuje nową w polskiej kulturze jakość - pojawiają się pierwsze znamiona kultury masowej. Odwołując się do klasycznego studium Kłoskowskiej, Żółkiewski konstatuje przekroczenie progu umasowienia około roku 1930. Konsekwencją, a zarazem symptomem tego procesu, jak pisze Żółkiewski, miało być między innymi pojawienie się nowego typu odbiorcy: o niepełnym wykształceniu, słabo obytego z literaturą wysokoartystyczną, wywodzącego się ze środowisk robotniczych.

Jacek Kolbuszewski, odnosząc się do rozważań Żółkiewskiego, dostrzega „oznaki masowości” wcześniej, mianowicie już w pierwszych la-

14 Takie określenie pojawia się w obu tekstach Balcerzana, zamieszczonych w tomie Problemy socjologii literatury, op. cit.

15 S. Morawski, Sztuka łatwa i sztuka trudna (Szkic wstępnej problematyki), w: O wspólczesnej kulturze literackiej, red. S. Żółkiewski, M. Hopfinger, t. 2, Wrocław 1973.

16 W. Grajewski, Powieść - kicz - ideologia, w: O wspótczesnej kulturze literackiej, t. 1, op. cit.

17 Z. Jarosiński, Literatura popularna a problemy historycznoliterackie, w: Formy literatury popularnej, op. cit., s. 13.

18 Por. J. Dunin, Papierowy bandyta. Książa kramarska i brukowa w Polsce, Łódź 1974; A. Gemra, „Kwiaty zla” na miejskim bruku. O powieści zeszytowej XIX $i$ XX wieku, Wrocław 1998.

${ }^{19}$ S. Żółkiewski, Kultura literacka 1918-1932, Wrocław 1973. 
tach XX wieku. Stawia on tezę, że dla rozwoju dwudziestowiecznej kultury polskiej, może zwłaszcza w jej obiegu masowym, przemiany zachodzące w okresie Młodej Polski miały kluczowe znaczenie, zaś analizowane przez Żółkiewskiego, międzywojenne zjawiska były ich kontynuacją. Pisze:

W istocie [...], właśnie w tym czasie, na przelomie XIX i XX wieku, zapoczątkowane zostały procesy umasowienia kultury, których intensyfikacja nastąpić miała dopiero z początkiem dwudziestolecia międzywojennego, już po odzyskaniu przez Polskę niepodległości. Był to więc okres swoistego „usamodzielniania” się literatury popularnej, jej, by tak rzec, samoświadomego wyodrębniania się ${ }^{20}$.

Kolbuszewski polemizuje również z proponowanym przez Żółkiewskiego modelem odbiorcy. Zgadzając się zasadniczo na wskazane wyznaczniki społeczne, stwierdza, że zawężają one pole widzenia. Należaloby, jego zdaniem, mówić o nowym typie odbiorcy wyodrębnionym kulturowo, a nie społecznie. Kolbuszewski rozważa takie dane historyczne, jak: wysoki stopień przyrostu liczby ludności, szybkie tempo rozwoju miast, rozrost proletariatu, a także inteligencji, dynamika rozwoju ruchu wydawniczego, rosnąca koncentracja życia kulturalnego w miastach, a jednocześnie aktywizacja ośrodków prowincjonalnych ${ }^{21}$. Z przeprowadzonej analizy wnioskuje, że:

Na przełomie XIX i XX wieku zaistniały pełne warunki do wykształcenia się sporej liczebnie grupy nowej publiczności literackiej, reprezentującej typową „klasę średnią", nie tylko w społeczno-ekonomicznym znaczeniu, ale także a może: zwłaszcza - w sensie kulturowym ${ }^{22}$.

Odbiorcy rodzącej się literatury popularnej za jej pomocą zapełniali sobie "pustkę kulturową", będącą następstwem porzucenia swoich poprzednich kręgów kulturowych i znalezienia się na nowej orbicie"23. Jego zdaniem:

Czytelnik ów $[\ldots]$ reprezentował zupełnie nowe środowisko uczestników życia kulturalnego, wykupywał i pilnie czytywał różnego rodzaju poradniki towarzyskie dobrych manier. Był więc owym czytelnikiem najzwyczajniejszym... filister, nowy mieszczanin, co wcale nie znaczy, że nowobogacki. Drobnomieszczański ćwierćinteligent $\mathrm{w}$ jakiejś mierze był produktem deklasowania się szlachty, w jakiejś - owocem awansu społecznego warstw niższych, reprezentował zatem ową ćwierćinteligencję mieszczańską, która wyraźnie poziomem wznosiła się ponad standardy drobnomieszczańskie ${ }^{24}$.

20 J. Kolbuszewski, Od Pigalle po Kresy. Krajobrazy literatury popularnej, Wroclaw 1994, s. 20.

21 Tamże, s. 22-23.

22 Tamże, s. 24.

23 Tamże, s. 28.

${ }^{24}$ Tamże, s. 21. Należy zwrócić uwagę, ze wśród czytelników literatury popularnej Kolbuszewski nie wymienia chłopów. Nie jest to przeoczenie - chłopi byli odbiorcami 
Koncepcja Jacka Kolbuszewskiego o kulturowo wyróżnionym odbiorcy literatury popularnej współgra z poglądem Zbigniewa Jarosińskiego o społecznie ograniczonym, a faktycznie szerokim adresie powieści popularnej (Trędowatq czytali wszyscy). Wiąże się to z odróżnieniem czytelnika „wirtualnego" od „faktycznego".

Literatura wysoka zakłada odbiorcę uniwersalnego, literatura popularna odbiorce społecznie zakorzenionego [...]. Warto na marginesie zauważyć, że z odbiorcą konkretnym rzecz ma się akurat odwrotnie. Literaturą wysoką interesują się stale środowiska łatwe do wyodrębnienia i raczej zwarte: przede wszystkim inteligencja (zwłaszcza inteligencja o wyksztalceniu humanistycznym, a w latach dwudziestych i niektóre kręgi ziemiaństwa) oraz pewne grupy robotnicze i chłopskie prowadzące działalność samokształceniową. Niezmiernie trudno natomiast określić społeczną przynależność czytelników literatury popularnej. Można przypuścić, że rekrutują się oni zarówno $\mathrm{z}$,wykształconego ogółu" wszelkich zawodów (również humanistów i intelektualistów), jak mas drobnomieszczaństwa, chłopów i robotników [...]. Społecznie określony czytelnik wirtualny i społecznie nieokreślony czytelnik rzeczywisty ujawniają się jako swoje przeciwieństwo 25 .

Tutaj w sukurs przychodzi kulturowo określony czytelnik wirtualny według koncepcji Jacka Kolbuszewskiego. Rozróżnienie Jarosińskiego przez odwołanie do kategorii czytelnika wirtualnego umieszcza kwestię popularności we wnętrzu tekstu. Innymi słowy, zagadnienie popularności powieści popularnej ujmuje od strony poetyki immanentnej. To, że potencjalnym odbiorcą powieści popularnej może być każdy, osiągane jest przez określone strategie tekstowe.

Intuicja ta towarzyszyla badaczom od początku refleksji nad charakterem literatury popularnej, jednak najbardziej wnikliwie i przekonująco operacjonalizuje ją Anna Martuszewska. Nadrzędną kategorią badawczą jest dla niej uproszczenie ${ }^{26}$, które to pojęcie umożliwia sformułowanie wyrazistej tezy o poetyce immanentnej ${ }^{27}$ literatury popularnej. W ujęciu Martuszewskiej najważniejszą cechą literatury popularnej jest powielanie (upraszczanie) właściwości literatury wysokoartystycznej28.

literatury brukowej (por. J. Dunin, op. cit.). Tymczasem literatura popularna, jak zauważa Jarosiński, przewiduje odbiorcę, którego edukacja czytelnicza jest zamknięta i ograniczona, ale osiągnęła dosyć wysoki poziom, na przełomie wieków chłopom niedostępny.

$25 \mathrm{Z}$. J a rosiń ski, op. cit., s. 28-29.

${ }^{26} \mathrm{O}$ wielorako pojmowanej kategorii uproszczenia pisze A. Martuszewska, w: Jak szumi „Dewajtis”? Studia o powieściach Marii Rodziewiczówny, Kraków 1989 (rozdział Upraszczanie struktur, s. 42-79; „Ta trzecia”, s. 16-18; także rozdział Upraszczanie struktur (niektóre problemy narracji powieści popularnej).

27 A. Martuszewska, "Ta trzecia”, op. cit., s. 6, passim.

${ }^{28}$ Należy zastrzec, że ta kategoria badawcza okazuje się przydatna szczególnie względem literatury z przeszłości (Martuszewska pisze duzo o przełomie XIX i XX w.). Wspólczesna literatura popularna wykształciła własne konwencje, a proces zapożyczania 
Uproszczenie ujmuje badaczka wieloaspektowo, jej zdaniem dokonuje się ono właściwie na każdym poziomie. Martuszewska wymienia uproszczenie struktur narracji, schematów fabularnych, konstrukcji postaci, które jej zdaniem dają się sprowadzić do paru wyróżnionych przez nią typów (o tym poniżej). Uproszczeniu ulegają też „liczba i rodzaj możliwych punktów widzenia narratora", co prowadzi do jednoznacznej waloryzacji poszczególnych elementów świata przedstawionego ${ }^{29}$.

Zbigniew Jarosiński stwierdza, że w strukturze językowej powieści popularnej dają się zauważyć dwie przeciwstawne tendencje.

Biegun pierwszy stanowiła tendencja do przyporządkowania języka fabule: wyrażała się ona w tym, aby wszystkie jednotematyczne epizody ujmować w klamry stylu sprawozdawczego, neutralnego, opisującego bieg wypadków, oraz aby dokonywać zdecydowanych wyborów między okolicznościami ważnymi [...] i obojętnymi z punktu widzenia fabuły $[. .$.$] . Biegunem drugim była tendencja do sty-$ listycznej samodzielności, rzutkości językowej, metaforyczności opisu $[\ldots]^{30}$.

Trzeba tu poczynić pewne zastrzeżenia. Sądzę, po pierwsze, że nie są to tendencje biegunowe, a komplementarne (co zresztą zdaje się zakładać Jarosiński). Po drugie, wątpliwości budzą "stylistyczna samodzielność” i „rzutkość językowa”. Otóż wydaje mi się, że językowa in nowacyjność młodopolskiej prozy popularnej jest chybiona. Inicjatywa stylistyczna autorów przejawia się $\mathrm{w}$ sposób zadziwiający: opiera się o przesadę i niewspółmierność środków językowych do przedstawianych zjawisk czy wydarzeń ${ }^{31}$. Wiąże się to $\mathrm{z}$ trafną, wprowadzoną przez Annę

- jakiego przypadkiem szczególnym jest uproszczenie - zachodzi niekiedy w odwrotnym kierunku, tzn. od popularnej do wysokoartystycznej. Ponadto w dzisiejszym obiegu literatury rozróżnienie tego, co popularne, od tego, co elitarne, jest trudne do utrzymania, a na pewno do operacjonalizacji.

29 A. Martuszewska, Ta trzecia, op. cit., s. 17. Odpowiednikiem uproszczenia byłoby oswojenie według terminologii Jacka Kolbuszewskiego; zob. J. Kolbuszewski, Oswajanie modernizmu. O poetyce powieści popularnych lat 1896-1905, w: W kręgu historii $i$ teorii literatury. Ksiega ku czci profesora Jana Trzynadlowskiego, red. A. Bazan, B. Zakrzewski, Wrocław 1987.

${ }^{30}$ Z. Jarosiński, op. cit., s. 24.

31 W Hedone Mieczysława Srokowskiego można spotkać zgoła swoistą interpretację motywu splotu milości i śmierci: nimfa w trakcie aktu płciowego z centaurem zostaje rozdarta przez jego zbyt duże przyrodzenie. Z kolei w Trędowatej opis kotyliona - wysoce skonwencjonalizowanego tańca towarzyskiego - zakrawa na charakterystykę rytuału: „Szał ogarnął tańczących, przeszedl we wzajemne oświadczanie się sobie za pomocą kwiatów. Upajająca woń roślin, roznamiętnienie, czar unosil się w blaskach sali, omotując wszystkich niebezpieczną siecią, przeźroczą jak mistyczna jakaś pajęczyna (t. 1, s. 321)". Tutaj niewspólmierność jest podwójna, bo występuje także w obrębie tego, co przedstawione: „Waldemar otrzeźwiał pierwszy i zakończył kotyliona huczną figura mazurową" (tamże). Trędowata słynie zresztą ze smakowitych fragmentów, jak na przykład ten, kiedy Stefcia „miała wrażenie, że coś wisi w powietrzu i spadnie jej na głowę” (t. 2, s. 11). Styli- 
Martuszewską kategorią pretensjonalności, która stanowi przeciwieństwo, a zarazem dopełnienie kategorii uproszczenia. Relację tę badaczka definiuje następująco:

Poziom językowo-stylistyczny - a częściowo także kompozycyjny utworów należących do literatury popularnej przede wszystkim daje się opisać za pomoca kategorii uproszczenia z jednej strony oraz pretensjonalności $\mathrm{z}$ drugiej [...]. Uproszczenie wiąże się z dalszymi kategoriami, mającymi już wyraźne aspekty socjologiczne i psychologiczne, także oczywiście znanymi poetyce historycznej, takimi jak stereotyp, klisza i schematy. [...] Pretensjonalność natomiast - stosunkowo o wiele mniej w literaturze popularnej zauważana przejawia się poprzez kategorię naśladownictwa (w tym wypadku polegającego na szczególnym rodzaju intertekstualności, tj. celowym odwołaniu się do literatury pięknej celem uzyskania specjalnej wartości dla opisów miłości, przeżyć bohatera wobec natury itp. ${ }^{32}$ [pogrubienie - A.P.].

Pojęcia wprowadzone przez Martuszewską nawiązują do propozycji niemieckiej badaczki Dorothee Bayer, która na językowym poziomie tekstu wyróżniła „banalność” i „wyszukaność”33. „Licytacja efektu”34, „stylistyczny barok"35, „styl jubilerski"36 czy inne efektowne formuły badaczy opisują to właśnie zjawisko.

Pretensjonalność przejawia się w dążeniu do jak największej ozdobności języka oraz, w mniejszym stopniu, fabuły. „Duża część literatury popularnej, przede wszystkim powieść sentymentalna i sentymentalnoobyczajowa, przeciwstawia własną «literackość» - zwykłej «językowości» literatury wysokiej" ${ }^{37}$. Jest to wyrazem aspiracji literatury popularnej do wysokoartystycznej: przyjmuje się, że w okresie Młodej Polski nie były one jeszcze wyraźnie rozdzielone ${ }^{38}$. Pojawia się tu problem wtórności literatury popularnej względem wysokoartystycznej. Powieść popularna, ogólnie mówiąc, powtarza pomysły z twórczości elitarnej, dodatkowo je wyjaskrawiając, przez co popada w afektację. Jej językowa in now acyj-

stycznym wynalazkiem Mniszkówny jest też chyba wytrwale podkreślanie piękna elektryczności - co zresztą sygnalizuje ambicję powieści, by być aktualną i nowoczesną.

32 A. Martuszewska, „Ta trzecia”, op. cit., s. 44.

33 Tamże, s. 43.

${ }^{34}$ A. Miciukiewicz, Schematy powieści popularnej. (Na marginesie powieści I. Zarzyckiej „Dzikuska”), „Litteraria” 1971: III, s. 167.

${ }^{35}$ M. Bujnicka, Erotyka romansu popularnego, op. cit., s. 6.

36 J. Now akow ski, $W$ kręgu obiegowych ideałów estetycznych, op. cit., s. 13.

37 Z. Jarosiński, op. cit., s. 29.

38 Tamże, s. 12. Przyjęcie tego poglądu - skądinąd uzasadnionego - sprawia, że literatura popularna wydaje się szczególnie efemeryczna: do początku XX w. jeszcze nie była wyodrębniona, od drugiej polowy XX w. znów rozmywają się granice literatury popularnej i elitarnej. Swiadczy to przede wszystkim o umowności kategorii badawczych (opartych na opozycji elitarne-popularne), które są równie silnie osadzone w kontekście, jak przedmiot badania. 
ność jest więc nie tylko chybiona, ale także pozorna. Pisze Alina Miciukiewicz o Dzikusce:

W układach fikcjonalnych konwencjonalnej prozy fabularnej słowa nie służą tworzeniu wielowarstwowych semantycznie aluzji, lecz konstruowaniu ukladów w sposób przejrzysty przekazujący określony zestaw treści. Nadmiar metafor i innych środków poetyckiego oddziaływania zakłóca „zwierciadlaność” przekazu, chyba że wprowadzone ozdobniki są tak schematyczne, że ich jednoznaczność uznamy za oczywistą ${ }^{39}$.

Słowa zatem zostają urzeczowione, funkcjonują na zasadzie rekwizytów czy „skorupy nomenklatury"40. Oprócz pozostałości po konwencjach sentymentalnych i romantycznych, na które wskazuje Miciukiewicz, czynnikiem sprzyjającym temu zjawisku była sama „młodopolszczyzna”. Młodopolskie poetyzmy przenikające do prozy, „hipertrofia stylu"41, jego maksymalna emocjonalność oraz wyrazistość, powodują, że był on szczególnie podatny na przejaskrawienia ${ }^{42}$. Dochodzi do pewnego rodzaju zapętlenia - ozdobność, która miała być rękojmią wysokiej jakości estetycznej, w swej krzykliwości prowadzi do schematyzacji czy wręcz automatyzacji języka, opartego o zbanalizowane środki stylistyczne. Za sprawą stylistycznej hipertrofii literatura popularna odsuwa się od elitarnej.

Przekształcenie środków stylistycznych oraz motywów fabularnych w klisze pełni istotną funkcję narracyjną. Wzmaga ono mianowicie kondensację fabuły i usprawnia jej odbiór.

Nasuwa się pytanie, w jaki sposób operowanie kliszami wpływa na kategorię prawdopodobieństwa, która wszak miała kluczowe znaczenie dla historycznoliterackich źródeł literatury popularnej, wśród jakich znajdują się sentymentalna powieść obyczajowa, ale także realistyczna powieść pozytywizmu43. Ta zaś w swojej klasycznej postaci, ukształto-

${ }^{39}$ A. Miciukiewicz, op. cit., s. 167.

40 Por. R. Nycz, Język modernizmu. Doświadczenie wyobcowania i jego konsekwencje, w: te go ż, Język modernizmu. Prolegomena historycznoliterackie, Wrocław 2002, s. 62-72.

41 Określenie Michała Głowińskiego w odniesieniu do Historii manjaków Romana Jaworskiego. Zob. M. Głowiński, Sztuczne awantury (Wstęp), w: R. Jaworski, Historie manjaków, Kraków 1978.

42 I na parodię. Pisze Ryszard Nycz: "Młodopolszczyzna” jako dominujący wzorzec stylistyczny odsłania w tym kontekście swój niezamierzenie autoparodystyczny charakter. Stosując hiperboliczny i emfatyczny wysoki styl jako formę artykulacji nie tylko doniosłej i poważnej, lecz także najbardziej banalnej, pospolitej czy trywialnej problematyki, realizuje typ strategii artystycznej uznawany $\mathrm{z}$ dawna za kluczowy mechanizm parodii" - Parodia i pastisz. Z dziejów pojęć artystycznych $w$ świadomości literackiej XX wieku, w: tegoż, Tekstowy świat. Poststrukturalizm a wiedza o literaturze, Kraków 2000, s. 212.

${ }^{43}$ Por. A. Martuszewska, Powieść i prawdopodobieństwo, Gdańsk 1992; tejże, Poetyka polskiej powieści dojrzałego realizmu, Wrocław 1977. 
wanej przez najwybitniejszych $\mathrm{w}$ XIX wieku reprezentantów gatunku, została zabsolutyzowana jako wzorzec ${ }^{44}$. Wydaje się, że dodatkowo wyjaskrawione „rozpasanie stylistyczne” 45 , charakteryzujące również wysokoartystyczną twórczość Młodej Polski, prowadzi w pierwszym rzędzie do naruszenia prawdopodobieństwa. Dokonuje się „wyobcowanie przez język"46.

Innym czynnikiem rozmywającym prawdopodobieństwo jest silne skontrastowanie poszczególnych elementów świata przedstawionego. Dotyczy to bohaterów, którzy często są czytelnie podzieleni na pozytywnych i negatywnych, zaś ich motywacje zostają sprowadzone do niezłożonych, za to niezwykle wytężonych uczuć i impulsów. Ale chodzi także o maksymalne aksjologiczne nacechowanie niektórych skladników świata przedstawionego, tak że ulegają one absolutyzacji, a wszystko inne jest im podporządkowane. Taka jest sztuka w Chimerze Jaroszyńskiego, miłość własna Panny Mery u Tetmajera, ale przede wszystkim - miłość, warunek konieczny romansu ${ }^{47}$. Zarazem gra przeciwstawnych wartości $\mathrm{w}$ popularnym romansie jest $\mathrm{z}$ góry przesądzona - prymat miłości to przecież romansu cecha definicyjna. Gdy zaś wynik gry o wartości jest znany, prawdopodobieństwo jest utrudnione czy dyskusyjne. W ten sposób silna ideologizacja, dokonująca się także przez waloryzację językową, blokuje prawdopodobieństwo.

Gmachy zbudowane $\mathrm{z}$ bardzo kolorowych klocków nie przypominają rzeczywistych budowli. Jacek Kolbuszewski mówi wręcz o „zasadzie nieprawdopodobieństwa", organizującej prozę popularną ${ }^{48}$. Przenikliwie zauważa jednak Piotr Kowalski:

Owo dostrzegane $\mathrm{z}$ „zewnętrznej” perspektywy nieprawdopodobieństwo spotyka się $\mathrm{z}$ wysoką przewidywalnością wewnątrztekstową: zdumiewające zdarzenia, przerażające fakty, niespodziewane rozwiązania nie tylko są zapowiadane przez wiele sygnałów rozmieszczonych $w$ tekście, ale przede wszystkim są ,spodziewane" na mocy rozpoznanych, aktualizowanych przez tekst, uniwersalnych schematów ${ }^{49}$.

Erozja prawdopodobieństwa w romansie czy - szerzej - w literaturze popularnej okresu Młodej Polski nie posuwa się aż do jego zniesienia.

44 Por. M. Głowiński, Powieść mlodopolska. Studium z poetyki historycznej, Kraków 1997 (rozdział III Sytuacja powieści mlodopolskiej).

${ }^{45}$ T. Walas, Bez szlachectwa, op. cit., s. 6.

46 R. Nycz, Język modernizmu. Doświadczenie wyobcowania $i$ jego konsekwencje, op. cit.

47 Podobna dystrybucja wartości ma genezę baśniową.

48 J. Kolbus zew ski, Od Pigalle po Kresy, op. cit., s. 29.

49 P. Kowalski, Oswojony świat literackiej fikcji, w: tegoż, (Nie)bezpieczne światy masowej wyobraźni. Studia o literaturze i kulturze popularnej, Opole 1996, s. 23. 
Nie pozwalają na to aktywne związki z literaturą elitarną, posługującą się tą kategorią. Ponadto rozluźnienie rygoru nie wydaje się $\mathrm{w}$ tym kontekście wadą. Odsunięcie się od „prozy życia” w stronę prozy ultraliterackiej jest warunkiem zadziałania odnoszących się do relacji bohaterczytelnik mechanizmów identyfikacji i projekcji, które Edgar Morin uważa za szczególnie istotną właściwość oddziaływania literatury popularnej. Pisze on, że

optymalne dla niej [identyfikacji] warunki stanowi pewna równowaga pomiędzy realizmem a idealizacją; trzeba poza tym, aby spełnione były warunki prawdopodobieństwa i wiarygodności [!], co wzmacnia związki z przeżywaną rzeczywistością. Trzeba dalej, aby postaci-obiekty identyfikacji wykazywały jakieś powinowactwo ze spotykanymi na co dzień ludźmi, ale trzeba także, aby ów świat wyobraźni wznosił się na kilka pięter ponad życiem codziennym, aby postaci te żyły intensywniej i obdarzone były większą siłą miłości, większym bogactwem uczuć niż zwykli śmiertelnicy ${ }^{50}$.

Do zbliżonych wniosków dochodzi Teresa Walas, analizując Trędowata ${ }^{51}$. W literaturze ma się pojawić lepsza wersja życia, ale mimo wszystko - całość ma pozostawać w zasięgu czytelnika ${ }^{52}$. Jak sentencjonalnie zauważył Umberto Eco: „Utożsamiamy się nie z tym, kto kradnie bombę atomową, a $\mathrm{z}$ tym, kto prowadzi luksusową motorówkę"53.

Drugą, rzadziej dostrzeganą stronę licznego występowania klisz w prozie popularnej, komentuje również Teresa Walas:

Powieść popularna szarzeje i cichnie [względem baśni i dawnych romansów], by kupić sobie podobieństwo do rzeczywistości. Jawna nieprawda jest bowiem już bez znaczenia, konieczne jest uwierzytelnienie wiarygodności niewiarygodnego świata. Staje się on na tyle uproszczony i na tyle bogaty w szczegóły, by wytrzymał ciężar konwencji i jednocześnie bez trudu dal się rozpoznać jako podobny, a więc mający pozory prawdziwości. Dlatego powieści popularnej tak służy wtórność i banał. Nie tylko ze względu na to, że karmi umysłowe lenistwo, ale

${ }^{50}$ E. Morin, Duch czasu, przeł. A. Frybesowa, Warszawa 1963, s. 79; cyt. za: A. Martuszewska, Jak szumi „Dewajtis”?, op. cit., s. 100.

51 „Trędowata nie jest więc złą powieścią obyczajową, lecz skwapliwie a naprędce przebranym romansem, wywodzi się z konwencji, w której schemat i idealizacja nie byly ułomnością i odstępstwem, lecz prawem i regułą, gdzie bohaterki były szlachetne i piękne, bohaterowie nieprześcignieni, a łajdacy nikczemni, gdzie prawdopodobieństwo jawnie ustępowalo ludzkiemu marzeniu i tęsknocie do porządku" - T. Walas, Poslowie, w: H. Mniszkówna, Trędowata, t. 2, Kraków 1972, s. 312.

52 Te poglądy współczesnych badaczy ciekawie korespondują z uwagami Arystoteles a na temat bohatera tragicznego. Ten mial „nie wyróżniać się osobliwie ani dzielnością i sprawiedliwością", ani podłością, miał być jednak "raczej lepszy niż gorszy” - Poetyka, przeł. i oprac. H. Podbielski, Wrocław 1989, BN II 209, s. 42-43.

53 U. Eco, Superman $w$ literaturze masowej. Powieść popularna: między retoryka a ideologia, przel. J. Ugniewska, Warszawa 1996, s. 225. 
przede wszystkim dlatego, że usypia podejrzliwość i czujność, najłatwiej utwierdza wiarygodność przez dobrze znane i powszechne. Sceneria i otoczenie złożone z oczywistych rekwizytów - realiów oraz utrwalonych w literaturze i potocznej świadomości stereotypów postaci i sytuacji otrzymuje charakter dekoracji, która nie oddaje rzeczywistości, lecz porozumiewawczo ją sugeruje, zaspokaja najskromniejsze pragnienie prawdziwości ${ }^{54}$.

Językowy świat powieści jest zagracony literackimi starociami - na ogół nie są to antyki, a zwykłe meble z pałacowego strychu. Są one wysłużone, ale wygodne, funkcjonalne i przyjazne swoim użytkownikom. Pojawia się tu nowy sposób interpretacji dychotomii uproszczenie-pretensjonalność, sygnalizujący dostrzeżenie ich waloru pragmatycznego. Maria Bujnicka stwierdza:

W romansie popularnym dokonywała się bowiem selekcja zdarzeń i rekwizytów właśnie pod kątem ich znakowego charakteru. Sytuacje, gesty, stroje, wnętrza wszystko to komunikowało $[\ldots]^{55}$.

Co więcej, wszystko to komunikowało już znane treści, przez co powieść popularna nabyła cechę redundancji. Wiąże się to $\mathrm{z}$ dostrzeżoną przez Jarosińskiego prawidłowością układania cech (bohaterów, elementów świata przedstawionego) i epizodów w synonimiczne ciągi znaczeniowe 56 .

Pod pozorem mechanizmu wytwarzającego informację kryje się mechanizm wytwarzający redundancję - pisze Eco. - Powieść udaje, że porusza czytelnika, w gruncie rzeczy jednak utwierdza go w umysłowym lenistwie i dostarcza pretekstu do ucieczki od rzeczywistości, nie opowiada bowiem o czymś nieznanym, ale przeciwnie, o czymś, co jest dobrze znane ${ }^{57}$.

Warto zauważyć - zgodnie z sugestią Aliny Miciukiewicz - że próby przełamania tej schematycznej i natrętnej emfatyczności, którą nazwałam roboczo chybioną innowacyjnością, również odbywały się na obszarze wyznaczonym przez konwencję. Innymi słowy, repertuar przełamań był ograniczony, zaś jego brzegi wytyczały przewidywane upodobania czytelnicze. Jeżeli natomiast efekty kreatywności autorów wychylały się w stronę groteski, która podminowuje powierzchowną „kombinatorykę" klisz, to działo się tak bodaj nieświadomie. Znamienne, że w romansach poety Tetmajera językowych dziwolągów jest niewiele ${ }^{58}$ (stosunkowo więcej może w późniejszych powieściach, np. w Plynq̨cych falach).

${ }^{54}$ T. Walas, Bez szlachectwa, op. cit., s. 6.

${ }^{55}$ M. Bujnicka, Romans popularny - baśn kultury masowej, op. cit., s. 64 .

${ }^{56} \mathrm{Z}$. Jarosiński, op. cit., s. 24.

57 U. Eco, op. cit., s. 212.

58 Zresztą romanse Tetmajera dają asumpt do lektury dostrzegającej ich zamierzoną ironiczność. W tym kierunku idzie Józef Nowakowski, widząc w nich rozmyślną grę 
Ale sprowadzenie warstwy językowej prozy popularnej do wykwitów wątpliwej pomysłowości grafomanów byłoby niedopuszczalnym uproszczeniem. Trzeba oddać sprawiedliwość autorom prozy popularnej. Stosowali zróżnicowane środki, których użycie wymagało nieraz dużych umiejętności warsztatowych i precyzji, jak również wyczucia frazy w przypadku organizacji rytmicznej, czy plastycznej wyobraźni, gdy proponowano środki odnoszące się do wzroku. Niekiedy jednak osiągali wrażenie afektacji, a często - śmieszności.

Sklasyfikowanie utworów popularnych jako zatrzaśniętych między uproszczeniem a pretensjonalnością usunęłoby z pola widzenia istotną cechę poetyki literatury popularnej, jaką jest jej oparcie o schemat czy formułę ${ }^{59}$. W koncepcji Johna G. Caweltiego schemat to „konwencjonalny system tworzenia produktu kulturowego"60 - każdego produktu, nie tylko popularnego. Formuły funkcjonują w równym stopniu w literaturze popularnej, jak i w wysokoartystycznej, jednak pełnią inne funkcje. Piotr Kowalski tak tłumaczy pogląd amerykańskiego badacza:

W „wysokoartystycznej” kulturze formuly są [...] zaproszeniem do przelamania własnych granic. Zawierają w sobie niejako nakaz innowacji, i to zarówno w sferze formalnej, jak i prezentowanego modelu świata [...]. [Natomiast] kultura popularna jest $w$ tym ujęciu domeną „konserwatywnych”, ,inercyjnych” tendencji w społecznej świadomości, formuła zaś - zaproszeniem do trwania, do powielania, do zadomowienia się $\mathrm{w}$ jej standaryzowanym świecie. „Schematyczność" wypowiedzi jest odpowiednikiem małej podatności na zmiany świadomości potocznej61.

Konstrukcja schematu jest dwudzielna, złożona z członu "danego" (na mocy konwencji, tradycji, cech stylu) i „niewiadomej”, która stanowi element innowacyjny. Jednak $w$ literaturze popularnej także miejsce

z wzorcem trywialnego romansu. Gra ta oparta ma być na takiej aktualizacji romansowego wzorca, która przywołuje wszystkie jego podstawowe składniki, a zarazem podważa go przez przeładowanie tymi składnikami i intertekstualne nawiązania pomiędzy powieściami - por. J. Nowakowski, „Brukowce” Tetmajera, w: tegoż, W kregu obiegowych ideatów estetycznych, op. cit.

59 J.G. Cawelti, Koncepcja schematu $w$ badaniach literatury popularnej, „Literatura Ludowa", 1973:6.

60 J.G. Cawelti, Myth, Symbol and Formula, "Journal of Popular Culture", VIII (1974): 1; cyt. za: P. Kowalski, Parterowy Olimp. Rzecz o polskiej kulturze masowej lat siedemdziesiątych, Wrocław 1988, s. 64. Piotr Kowalski w tej i w poprzednio cytowanej książce omawia kulturę masową, sama zaś powyżej odżegnywałam się od wymiennego stosowania terminów „literatura popularna” i „masowa”. Jednak ustalenia teoretyczne Kowalskiego, jak sądzę, stosują się do obu, po części dlatego, że różnice między literaturą popularną a masową często są różnicami stopnia, por. J. Kolbuszewski, Od Pigalle po Kresy, op. cit., s. 10.

${ }^{61}$ P. Kowalski, op. cit., s. 67. 
„zmiennej” zajmują elementy silnie określone przez konwencje (z różnych poziomów: językowego, fabularnego i innych). Repertuar środków jest wstępnie zdefiniowany. W wyniku tego pojawiają się schematyzm (w potocznym znaczeniu) oraz sztampowość, ale jednocześnie wzrastają takie wartości istotne z perspektywy odbiorcy, jak zrozumiałość, przyjemność z rozpoznania konwencji, spełnienie życzeń formułowanych przez czytelnika wobec tekstu; życzeń, które ukształtowały się podczas wcześniejszych lektur i wynikają ze znajomości podobnych tekstów literackich.

Zatem na związaną z naśladownictwem pretensjonalność, w sposób iście dialektyczny powiązaną $\mathrm{z}$ uproszczeniem, można spojrzeć również $\mathrm{z}$ innej strony. Oferując czytelnikowi znany i przewidywalny zasób środków językowych i konwencji, gwarantowała ona ciągłość: gatunkową, stylistyczną, tematyczną. Jarosiński pisze:

W sytuacji szybkiej zmienności poetyk, bezustannych przewartościowań zastanego dziedzictwa, rozbieżności postaw pisarskich, literatura popularna okazuje się przystanią gustów względnie stabilnych, domeną walorów literackich sprawdzonych już w społecznej praktyce. Właściwy jej tradycjonalizm, przywiązanie do utartych rozwiązań fabularnych, wierność klasycznym sposobom narracji stanowią negatywny układ odniesienia dla usiłowań artystycznych zmierzających w stronę nowości ${ }^{62}$.

Już ten pobieżny przegląd stanowisk badawczych wobec literatury popularnej daje orientację $w$ wielopoziomowej niestabilności pojęcia. Literatura ta rozpięta jest między intuicyjną oczywistością terminu a uporczywymi trudnościami w zdefiniowaniu go. Rozpościera się między zrozumiałością wśród czytelników a trudnością opisu wśród badaczy; między wyznacznikami społecznymi, kulturowymi, kontekstowymi - a wewnątrztekstowymi; między obiegiem społecznym a poetyką immanentną; między uproszczeniem i pretensjonalnym odkształceniem poetyk wysokoartystycznych a autonomicznym, swoistym rozwojem poetyk immanentnych; między trywialnością a transcendencją; między przyjemnością czytelnika a bólem głowy badacza.

Moim zdaniem heterogeniczność, wspólistnienie różnych tradycji, a nawet ich poplątanie, są nieodłącznymi cechami literatury popularnej. Literatura popularna jest obszarem szczególnych spięć i sprzeczności, które tworzą dynamiczną, niestabilną, zróżnicowaną strukturę. Jej różne komponenty pozostają ze sobą w zmiennych relacjach, zaś aktualizowane są w zależności od koniunktury (kulturowej, rynkowej), od temperamentu, umiejętności i zamierzeń autora, od kontekstu, w którym powieść

62 Z. Jarosiński, op. cit., s. 13. 
ma zaistnieć. Nacisk położony na kontekst to właściwie odwołanie do odbiorców, którzy w nim żyją i czytają. Józef Nowakowski stwierdza nawet:

Literaturę popularną od literatury wysokiej wyróżnia moment szczególnie żywej aktualizacji czy wręcz ekspansji odbiorcy, którego świat pojęć i wyobrażeń w sposób zdecydowany wpływa na sam przebieg komunikacji. W tekście literatury popularnej są zakodowane - w stopniu o wiele wyższym niż to bywa w innych tekstach - wymagania przeciętnego odbiorcy ${ }^{63}$.

Niezależnie od tego, czego dokładnie wymaga ten przeciętny odbiorca,

poznawszy oczekiwania publiczności, trzeba zdecydować się, czy należy się im przeciwstawić, czy też je zaspokoić - pisze Umberto Eco. - Powieść „popularna” (powieść odcinkowa, feuilleton) jest nią dlatego, że wybiera drugie rozwiązanie, a zatem nawet wtedy, kiedy jest powieścią "demokratyczną", „populistyczną", pozostaje przede wszystkim "popularną", ponieważ jest „demagogiczną" [...]. Powieść popularna dąży do uspokojenia czytelnika, powieść problemowa zaś stawia go w stan konfliktu z samym sobą. Tu jedynie przebiega linia podziału, cała reszta może być (i często jest) wspólna [...]. Narracja nie może wykraczać poza granice nabytych przyzwyczajeń i systemu panujących wartości ${ }^{64}$.

Literatura popularna jest poczytna i wielokształtna, dlatego - między innymi - tak trudno ją metodologicznie uchwycić. Rozmaite gatunki, modele czy poszczególne dzieła w niejednakowym stopniu odnoszą się do tej żywiołowej, wciąż na nowo negocjowanej struktury. Czynnikami istotnymi są tu konwencje literatury wysokoartystycznej, dziedzictwo folkloru, prawa rynkowe (co mocno podkreśla Hernas ${ }^{65}$ ). W wyniku tych niejednokrotnie agresywnych negocjacji powstają utwory niespójne, hybrydyczne ${ }^{66}$ - ale poczytne.

I tak na przykład powieści Mniszkówny mają zdecydowanie baśniowy charakter, ale już romanse Mieczysława Srokowskiego odnoszą się do wysokoartystycznej tradycji wczesnego modernizmu (na przykład do D’Annunzia ${ }^{67}$ ), a nie do gatunków folklorystycznych. Dlatego, jak myślę, zbytnim uproszczeniem byłoby sprowadzanie ich do jednego wzorca.

Sądzę, że w okresie Młodej Polski współistniały dwie wersje romansu popularnego ${ }^{68}$ : „tendencyjno-baśniowy” i „naturalistyczny”. Sztandarową postacią modelu „tendencyjno-baśniowego” byłaby Helena Mniszkówna, ale także Natalia Bardzka, Wanda Grot-Bęczkowska, Maria Rodziewiczówna (wcześniej) czy Irena Zarzycka (później). W powieściach

63 J. Nowakowski, op. cit., s. 9.

64 U. Eco, op. cit., s. 18, 21, 36.

65 C. Hernas, Potrzeby i metody badania literatury brukowej, op. cit., s. 20.

66 Por. J. Nowakowski, op. cit., s. 58 ( mowa jest o Trędowatej).

67 Por. J. Now akowski, op. cit. (rozdział Polski D'Annunzio-Mieczystaw Srokowski).

68 Por. T. Walas, Bez szlachectwa, op. cit., s. 6. 
„tendencyjno-baśniowych" dochodzi do wymieszania wzorców literatury pozytywizmu (mówiąc ściśle, powieści tendencyjnej i dojrzałego realizmu) i baśni. Polega to na nałożeniu baśniowego schematu fabularnego, częstego w romansach sentymentalnych, i uproszczonych typów protagonistów, na mniej lub bardziej realistycznie przedstawione środowisko (przy czym powieść nie uchyla się też od realistycznego postulatu typowości). Pisze Teresa Walas:

Tradycja pozytywizmu była dla literatury popularnej dziedzictwem niezwykle cennym. Jego optymistyczny racjonalizm, tendencje moralizatorskie i lagodny humanizm wspierały rzetelnie filozofię popularnej powieści. Praca przynosi chlubę i pożytek. Nie ma złych ludzi, są tylko nieświadomi i nieszczęśliwi. Kokieteria jest szkodliwa i zgubna. Przeznaczeniem kobiety jest macierzyństwo. To był ten zasób przekonań, z którego najchętniej czerpała Zarzycka, a który kiedyś wypracowała Orzeszkowa jako autorka Pamiętnika Waclawy i... Na biegunach. Dzikuska jest romansem przepuszczonym przez powieść tendencyjną ${ }^{69}$.

Rekonstrukcję źródeł należałoby uzupełnić. Ukształtowana pod wpływem chrześcijaństwa (zwłaszcza katolicyzmu) moralność, z jej naciskiem na przyzwoitość i łagodność, w sposób znaczący uczestniczyła w regulowaniu życia codziennego z jednej, a gustów literackich - z drugiej strony. Widoczny jest tutaj podwójny konserwatyzm tego typu powieści: ideologiczny (w duchu konserwatyzmu mieszczańskiego) i formalny.

Podwójnemu konserwatyzmowi towarzyszy... podwójna niewierność:

Powieść popularna żyje [...] kompromisem: zachowany zostaje fundament starej konwencji [romansowej], ale całość otrzymuje pozory realizmu. Z kompromisu tego rodzi się podwójna niewierność: w stosunku do konwencji i w stosunku do rzeczywistości ${ }^{70}$.

Nałożenie różnych konwencji przynosi efekt $\mathrm{w}$ postaci tworów hybrydycznych, łączących jakości właściwe różnym tradycjom ${ }^{71}$.

Anna Martuszewska konsekwentnie uzasadnia tezę o pozytywistycznym rodowodzie pisarstwa Marii Rodziewiczówny ${ }^{72}$. W toku analizy badaczka wypracowała koncepcję romansu, którą rozwija w kolejnych pracach. Jej zdaniem,

model nie tylko polskiego, ale i światowego romansu powstaje [...] przez stopniowe przystosowywanie i upraszczanie społeczno-obyczajowej powieści wysokoartystycznej i połączenie jej z baśniowymi wątkami ${ }^{73}$.

69 Tamże.

70 Tamże.

${ }^{71}$ Listę stereotypowych chwytów w Trędowatej podaje J. Nowakowski, op. cit., s. $51-52$.

${ }^{72}$ A. Martuszewska, Jak szumi „Dewajstis”?, op. cit., passim.

73 Tamże, s. 182. 
Tymi baśniowymi elementami $\mathrm{w}$ tkance romansu są przede wszystkim schemat fabularny i konstrukcja bohaterów. Martuszewska wyróżnia dwa podstawowe schematy fabularne. Pierwszy z nich, schemat Kopciuszka, opisuje sytuację, w której zakochanych protagonistów dzieli pochodzenie z różnych sfer. Dla jednej z postaci związek z drugą byłby awansem społecznym - pojawia się więc znany z literatury pozytywistycznej motyw mezaliansu ${ }^{74}$. Na drodze do szczęścia kochanków stają liczne przeszkody, niekiedy uniemożliwiające wymarzone małżeńskie szczęście. Natomiast gdy fabuła układa się według drugiego schematu, pomysłowo nazwanego przez badaczkę wątkiem Pięknej i Bestii jedno $\mathrm{z}$ dwojga protagonistów jest skarbnicą cnót i zalet (moralnych, fizycznych, także intelektualnych), podczas gdy drugie wręcz przeciwnie, odznacza się miernością albo nikczemnością moralną, fizyczną, czasami również intelektualną. Piękna (najczęściej bohaterka) musi cierpieć uciążliwe awanse i rozmaite przykrości ze strony Bestii. Niekiedy pod wpływem miłości Pięknej, Bestia się przemienia, ale rzadko, raczej dochodzi do zniszczenia Pięknej, co fabularnie przybiera postać uwiedzenia dziewicy, trwałego rozstania, samobójstwa, obłędu.

Dwa typy schematów fabularnych uzupełnia binarny podział na pary protagonistów: Heros i Demon, Anioł i Kobieta Fatalna. Wymienione typy nie muszą występować zawsze, ale postaci pierwszo- i drugoplanowe bardzo często dają się do nich sprowadzić. Martuszewska poszukuje dla nich wzorców w mitach, a bardziej bezpośrednio - w baśniach, organizujących wydarzenia wokół pojedynczych postaci o skumulowanych cechach. Koresponduje to $\mathrm{z}$ poglądem Teresy Walas, wyrażonym na marginesie Trędowatej (jest to, przy okazji, świetna charakterystyka protagonisty w typie Herosa):

[Ordynat] Michorowski, jak wielu jego krewnych w literaturze popularnej, pochodzi w prostej linii od baśniowych postaci o spotęgowanym istnieniu, jak Waligóra, Wyrwidąb, odporny na złowrogie siły właściciel magicznych przedmiotów, niepokonany heros. Działają one w świecie groźnym, bardziej skomplikowanym i podstępnym niż świat zwykły, najeżonym trudnościami, które gładko pokonują, demonstrując swoją siłę. Los ich niezmiennie wyznaczony konwencją biegnie wśród przeszkód i niebezpieczeństw ku tryumfowi lub - rzadziej - ku katastrofie. Jeśli giną, to zwyciężeni podstępem, jak Herkules, nigdy - pokonani, nigdy - upokorzeni ${ }^{75}$.

Demon to nikczemny przeciwnik Herosa. Walczy z nim na różne sposoby, najchętniej nieczysto, sabotując jego poczynania lub posługując się podstępem. Cechuje go okrucieństwo, a jego motywy są zazwyczaj

${ }^{74}$ Por. T. W ala s, Poslowie, op. cit., s. 308.

75 Tamże, s. 313. 
podejrzane. Anioł to pozytywna bohaterka - śliczna panienka o gołębim sercu, ale żelaznej cnocie. Kobieta Fatalna odwrotnie, jest wyzwolona, erotycznie uświadomiona i chętnie manipuluje pozostałymi bohaterami.

Koncentracja na schemacie fabularnym i protagonistach nadaje opowieści wymiar uniwersalny, przez badaczy chętnie identyfikowany $\mathrm{z}$ dziedzictwem (filologicznie rozumianego) mitu. Martuszewska, powołując się na Northropa Frye'a, stwierdza, że motywy mityczne ulegają przemieszczeniu, które polega na

uwiarygodnieniu wątków i postaci baśniowych przez wpisanie ich w kształtowane na zasadzie prawdopodobieństwa ramy czasoprzestrzenne ${ }^{76}$.

Paraewolucjonistyczny schemat mit - baśń - literatura popularna budzi wątpliwości, podobnie jak nadane typom postaci nazwy, niewywodzące się z jednego porządku. Same jednak wyodrębnione w ten sposób typy protagonistów wydają się trafne.

Drugi model popularnego młodopolskiego romansu - „naturalistyczny" - dałby się zrekonstruować na podstawie tekstów Mikołaja Czernego, Gustawa Daniłowskiego, Exeter [Ludwiki Godlewskiej], Mariana Gawalewicza, Mieczysława Srokowskiego, Kazimierza Przerwy Tetmajera i innych. Tutaj diferencia specifica stanowiłoby nawiązywanie do konwencji powieści młodopolskiej i do naturalizmu, dokonujące się jednak w znamiennym a wielorakim uproszczeniu (wątków fabularnych, konstrukcji bohaterów) - ich oswajanie, jak sugestywnie określił to zjawisko Jacek Kolbuszewski77. Jego zdaniem,

obok Młodej Polski „wysokiej”, profetycznej, odznaczającej się swoistym arystokratyzmem czy elitaryzmem sztuki (estetyzm), a funkcjonującej w stosunkowo wąskim, częściowo nawet zamkniętym, kręgu odbiorców, dostrzegamy istnienie specyficznie młodopolskiej, a nawet modernistycznej literatury w jej wersji popularnej, świadomie zwracającej się do poszerzonego kręgu odbiorców i dosyć skutecznie wykorzystującej nowe, zmieniające się w wyniku procesów urbanizacyjnych ekonomiczne i społeczne warunki życia literackiego. Można ślady tego zjawiska dostrzec w poezji, ale najsilniej uzewnętrzniło się ono w powieści, wykorzystującej znamienne cechy poetyki powieści modernistycznej i naturalistycznej w postaci „oswojonej”, a zatem uproszczonej i dostosowanej do percepcyjnych możliwości mniej wyrobionego, acz nie pozbawionego pewnych aspiracji czytelnika $[\ldots]^{78}$.

Scharakteryzowany powyżej nowy typ czytelnika aspirował do uczestnictwa w bujnym i autentycznym życiu kulturalnym i intelektualnym. Oczekiwał też dostępu do prawdziwego artystycznego nowatorstwa.

76 Tamże, s. 98.

77 J. Kolbuszewski, Oswajanie modernizmu, op. cit.

78 Tamże, s. 56. 
Jednakże braki w zakresie kompetencji literackiej zamykały mu drogę do osiągnięcia estetycznego szczęścia w obcowaniu z literaturą wysokoartystyczną. Tutaj pomocna okazywała się właśnie wydzielająca się z elitarnej - proza popularna. Kolbuszewski zwraca uwagę, że powieści nader często opatrzone były komentarzem „współczesne”, co sygnalizowało, iż przynoszą zarówno najnowsze tendencje artystyczne, jak $\mathrm{i}$ tematy ${ }^{79}$.

A wówczas modny był naturalizm - pojmowany jako zespół brutalnie ujętych, drastycznych czy stabuizowanych tematów z życia współczesne$\mathrm{go}^{80}$. Jednak istotne kwestie, $\mathrm{z}$ rozmachem podejmowane $\mathrm{w}$ tekstach wysokoartystycznych, w powieści popularnej znajdują wyraz zgoła płaski i trywialny. Zostają sprowadzone do wyrazistych, zdroworozsądkowych, pikantnych czy malowniczych motywów. I tak: sztuka jest praktycznie zawsze niezbyt zaawansowaną sublimacją zawodu miłosnego. Bunt artysty zazwyczaj ogranicza się do ekscentrycznego stroju i pijackich ekscesów. Rewolucyjna i rewelatorska sztuka na ogól daje się sprowadzić, w najlepszym razie, do Böcklina, ale wcale często - Matejki ${ }^{81}$. Wiąże się to z zaprogramowaną dostępnością przekazu oraz dostosowaniem się do rozpowszechnionych norm estetycznych i moralnych ${ }^{82}$.

Losy ludzkie traktowane miały być biologistycznie, jak życie przyrody. Motywacją działań bohaterów stawała się fizjologia ${ }^{83}$. „Ważne jednak znaczenie miało także ukazywanie determinującej roli środowiska w kształtowaniu ludzi i sposobów ich postępowania"84. Za naturalistyczny uważano też obiektywistyczny styl, beznamiętnie relacjonujący brzydotę.

Jednym z najważniejszych sposobów aplikowania naturalizmu do materii prozy popularnej był wybujały erotyzm. Uzasadnienie znajdował on w naturalistycznym wydobyciu roli popędu płciowego, ale był to także istotny czynnik rynkowy, dodatkowo stymulujący do lektury. Wymownym przykładem trywializowania istotnych treści ideologicznych bylo wyrażanie kwestii narodowych i politycznych przez wątki erotyczne właśnie, jak na przykład w powieści Anny z Bardzkich Karwatowej Dwa zywioty, gdzie zły i chutliwy Niemiec ponosi karę za nastawanie na polską patriotkę. Natomiast Gustawa Daniłowskiego Jaskótka daje nie tyl-

79 Ten postulat aktualności zaowocował bujnym rozwojem powieści dziennikarskiej; por. J. Kolbuszewski, op. cit., s. 61.

80 M. Glowiński, Powieść mlodopolska, op. cit., s. 96.

81 Nie chcę przez to powiedzieć, że Böcklin był lepszy od Matejki (ani odwrotnie). Chodzi o pewnego rodzaju kulturalny poślizg, który cechuje powieść popularną.

${ }^{82}$ A. Miciukiewicz, op. cit., s. 163.

83 M. Glowiński, op. cit., s. 96.

${ }^{84}$ J. Kolbuszewski, op. cit., s. 64. 
ko obraz rewolucji 1905 roku, ale i niejedną scenę namiętności, niekiedy $\mathrm{w}$ nieoczekiwanych pod względem fabularnym konfiguracjach osobowych. Ogólnie w powieściach „naturalistycznych” znacznie większą rolę odgrywa erotyka - w modelu „tendecyjno-baśniowym” ledwie obecna, i to zazwyczaj albo cnotliwie stłumiona, albo uświęcona przed ołtarzem.

Naturalistycznym tendencjom zawdzięcza proza popularna Młodej Polski żywy rozwój powieści środowiskowej. Aktualizowana konwencja „studium” pozwalała na wgląd w kręgi obce czytelnikowi. Powieści nie stroniły od drastycznych obrazów, nie wahały się też ukazywać nędzy. Można by nawet powiedzieć, że tymi szokującymi efektami epatowały swoich nieszczęsnych mieszczańskich czytelników, dając im dreszczyk ekscytacji oraz możliwość podejrzenia środowiska dla nich egzotycznego.

Liczną i poczytną grupę stanowią powieści o artyście. Dawały one pretekst nie tylko do - choćby imaginacyjnego - podejrzenia „kapłana sztuki" przy pracy (to filisterskie marzenie gorzko ośmiesza dramat W sieci). Wiadomo było powszechnie, że artyści z racji swojego artyzmu są ponad normami moralnymi. Powieść o artyście umożliwiała więc fantazjowanie na temat artystowskich ekscesów. Szczególnie, że wiele spośród tych utworów czytano jako powieści z kluczem (jak Anioła śmierci Tetmajera czy Plotkę Gawalewicza).

Skoncentrowanie narracji na postaci głównego bohatera, częste i zrozumiałe $\mathrm{w}$ powieści o artyście, inicjuje nową problematykę. Stanowi mianowicie furtkę dla postulatów naturalizmu, jak na przykład praktyka „dokumentu ludzkiego”. W dalszej kolejności w zasób konwencji używanych $w$ prozie popularnej wprowadza narrację personalną. Tym samym, jak pisze Głowiński, dochodzi do przekształceń struktury narracji oraz warstwy językowej w kierunku ,impresjonizmu językowego"85. To zaś jest elementem ogólnych przemian, jakim podlegała powieść $\mathrm{w}$ okresie Młodej Polski. Można więc wnioskować, że powieści z nurtu „naturalistycznego" pod względem konstrukcji są bardziej nowoczesne, niż „tendencyjno-baśniowe".

Aby osłabić ewentualne wrażenie, że popularny romans młodopolski był naturalistyczny bez cudzysłowu, warto przywołać opinię Józefa Nowakowskiego o powieściach Tetmajera. Badacz upatruje w nich zależności nie tylko od współczesnych, zwłaszcza od Przybyszewskiego. Dostrzega również inspiracje sienkiewiczowskie (technika dialogów, rysunek figur, dowcip, niekiedy maniera) ${ }^{86}$, wskazuje także na bardzo wyraźne korzenie romantyczne ${ }^{87}$.

\footnotetext{
${ }^{85}$ M. Głowiński, Powieść mlodopolska, op. cit., s. 99.

86 J. Nowakow ski, op. cit., s. 80.

87 Tamże, s. 103.
} 
Oswajanie młodopolszczyzny objęło również dekadentyzm. Z nim było dosyć łatwo - realizował się on we wzorze bohatera fatalistycznego, cierpiącego na ból istnienia oraz zawód miłosny, który stara się ukoić egzystencjalną rozpacz metodami właściwymi dekadentom. $\mathrm{Z}$ tego powodu w powieściach „naturalistycznych” stosunkowo rzadziej występują typy bohaterów męskich, przez Martuszewską nazywane Herosem i Demonem. W zamian za to pierwszoplanowe heroiny regularnie stanowią wzory osobowe według schematu Anioła i Kobiety Fatalnej - pierwsza uosabia nadzieję na odkupienie, druga - chuć.

Dwa zaproponowane przeze mnie modele są zaledwie próbą uporządkowania bogatych i zróżnicowanych zjawisk. Już wtedy bowiem, u swoich początków (przynajmniej instytucjonalnych) literatura popularna była wielokształtna i wcale nie tak jednoznaczna, jak chcieliby ówcześni krytycy, a dzisiejsi badacze. 